\title{
Utilization of Industrial Effluent for Irrigation - Pros and Cons
}

\author{
S. David Noel ${ }^{*}$, M. R. Rajan \\ Dept of Biology, Gandhigram Rural Institute-Deemed University, \\ Gandhigram 624302, Tamil Nadu, India \\ *E-mail address: davidnoel_22@yahoo.co.in
}

Keyword: Pathogens; Industrial Effluent; Heavy Metals; Phytoremediation; Pollution

\begin{abstract}
Decreasing water level and shortage of water is being a major problem worldwide. For agriculture purpose this problem gives rise to the use of alternative sources of water. Most of these water sources are affected by the discharge waste of effluent from various types of industries like mining, textiles, chemical etc. Due to reason this effluent may contains many organic toxic substances that could have hazardous impact on human health. In addition, technological development has contributed to increase other industrial dumping that contaminates surface waters. The irregular disposal of industrial effluent has created pollution problems since this effluent is disseminated in the environment or is accumulated in sediments, aquatic organisms, and water. In this paper a solution for this global issue has been addressed and strategies have been suggested for this problem.
\end{abstract}

\section{INTRODUCTION}

Industrial or municipal wastewater is mostly used for the irrigation of crops, mainly in periurban ecosystem, due to its easy availability, disposal problems and scarcity of fresh water. The growth of human population, industrial and agricultural practices is the major causes of pollution (Eguabor, 1998). Use of industrial effluent and sewage sludge on agricultural land has become a common practice in India as a result of which these toxic metals can be transferred and concentrated into plant tissues from the soil. These metals have damaging effects on plants themselves and may become a health hazard to man and animals. Above certain concentrations and over a narrow range, the heavy metals turn into toxins. (Schiffenbauer and Stotzky, 1982). The disposal of effluent is a major problem faced by municipalities, particularly in the case of large metropolitan areas, with limited space for land based treatment and disposal. On the other hand, effluent is also a resource that can be applied for productive uses since effluent contains nutrients that have the potential for use in agriculture. Thus, effluent can be considered as both a resource and a problem. Effluent and its nutrient content can be used extensively for irrigation and other ecosystem services. Its reuse can deliver positive benefits to the farming community (Hari,et al,1994). However, irrigating plants with effluent of salinity higher than the crop can tolerate will result in reduction in vegetative growth, yield loss and may decrease crop quality. The various species and cultivars vary greatly in their tolerance to irrigation with such water. Wastewater damage to plants is produced by a combination of several causes, including mainly osmotic injury (Briccoli et al, 1994). The use of wastewaters (industrial effluents as well as municipal Sewage) for irrigation has emerged in the recent past as an important way of utilization of waste water taking the advantage of the presence of considerable quantities of nitrogen and phosphorus along with some other essential elements. Other advantage of effluent irrigation includes an important aspect of pollution removal. The pollutants are partly taken up by the plants and partly transformed in the soil without causing any damage. Nevertheless, the use of wastewaters for agriculture is marred by several constraints due to various problems like soil salinity, interaction of chemical constituents of the wastes with the uptake of nutrients and changes in soil property and micro flora (Goel and Kulkarni, 1994). However several micronutrients are heavy metals and known to produce undesirable effects on plants at higher 
concentrations. Accumulation of toxic heavy metals leads to stress conditions in the plant system by interfering with the metabolic activities and physiological functioning of the plants. Heavy metals are known to cause membrane damage, structural disorganization of organelles, impairment in the physiological functioning of the plants and ultimately growth retardation. (Chien and Kao, 2000).

\section{BENEFITS OF USING EFFLUENT FOR IRRIGATION}

There are many potential benefits offered by the use of municipal effluent for irrigation purposes, including the safe and low-cost treatment and disposal of waste water; the conservation of water and recharge of groundwater reserves; and the use of nutrients in the effluent for productive purposes. The irrigation of trees may provide additional benefits. In areas where water is relatively plentiful, crop or forestry irrigation may be adopted primarily for treatment and disposal purposes. In arid and semi-arid zones, the issues of groundwater recharge and tree and crop production may be equally or more important.

\section{SAFE, LOW-COST TREATMENT AND DISPOSAL}

If insufficiently treated or improperly disposed of effluent constitutes a source of pollution and a health hazard. However, the cost of treatment using conventional methods is high, prohibitively so for most developing countries. As a result, countries are experimenting with other forms of treatment, among which are land application methods, including irrigation. When practiced properly, these are simple, low-cost and effective means both to dispose of effluent and to improve its quality. Where effluent is already treated, this practice can further improve its quality at a low cost. When limited pretreatment is available, it may provide a means of disposal which poses the least risk of disease and environmental damage. The irrigation of trees is likely to pose fewer health risks and be more socially acceptable than the irrigation of crops.

\section{NUTRIENTS FOR CROP PRODUCTION}

Raw sewage and even secondary treated effluent are rich in mineral nutrients needed for plant growth. Experiments have repeatedly demonstrated an increased productivity of crops or trees when irrigated with effluent as compared with clean water. These nutrients represent a resource of considerable value when compared with the equivalent cost of fertilizer. The application of waste water at rates which ensure a balance between nutrient input and plant uptake will promote optimal plant growth while limiting the risks of pollution.

\section{POTENTIAL RISKS FROM USING RECYCLED EFFLUENT}

Water pollution leads to damage to human health. Disease carrying agents such as bacteria and viruses are carried into the surface and ground water. Drinking water is affected and health hazards result (Owa, 2014). There have been a number of risk factors identified for using reused effluent for purposes such as agricultural irrigation. Some risk factors are short term and vary in severity depending on the potential for human, animal or environmental contact (eg, microbial pathogens), while others have longer term impacts which increase with continued use of recycled effluent (eg, saline effects on soil).

\subsection{PATHOGENS}

The most common human microbial pathogens found in recycled effluent are enteric in origin. Enteric pathogens enter the environment in the faeces of infected hosts and can enter water either directly through defecation into water, contamination with sewage effluent or from run-off from soil and other land surfaces (Feachem et al. 1983). 


\section{- VIRUSES}

Enteric viruses are the smallest of the pathogens found in water. The majority of these viruses can be commonly detected in faecal contaminated water, for example sewage effluent, Most enteric viruses have a narrow host range meaning that most viruses of interest in recycled water only infect humans (Haas et al. 1999). This means that only human faecal contamination of water need be considered a concern for viral infection of humans.

\section{- BACTERIA}

Bacteria are the most common of the microbial pathogens found in recycled waters (Toze 1999). There are a wide range of bacterial pathogens and opportunistic pathogens which can be detected in wastewaters. Many of the bacterial pathogens are enteric in origin, however, bacterial pathogens which cause non-enteric illnesses (e.g., Legionella spp., Mycobacterium spp., and Leptospira) have also been detected in wastewaters.

\section{- PROTOzOA}

There are several protozoan pathogens which have been isolated from wastewater and recycled water sources (Gennaccaro et al. 2003). The most common detected are Entamoeba histolytica, Giardia intestinalis (formerly known as Giardia lamblia) and Cryptosporidium parvum. Infection from all three of these protozoan pathogens can occur after consumption of food or water contaminated with the cysts or through person to person contact.

\section{- HELMINTHS}

Helminth parasites commonly detected in effluent that are of significant health risk in reused waters include the round worm (Ascaris lumbricoides), the hook worm (Ancylostoma duodenale or Necator americanus), and the whip worm (Trichuris trichiura).

\subsection{THREAT POSED BY HEAVY METALS IN EFFLUENTS}

Trace quantities of certain heavy elements, such as chromium, cobalt, copper, manganese and zinc are essential micronutrients for higher animals and for plant growth (Somers, 1974). Lead $(\mathrm{Pb})$, cadmium $(\mathrm{Cd})$, and nickel (Ni) are significant environmental pollutants. Anthropogenic activities, such as agriculture, industry and urban life increase the $\mathrm{Pb}, \mathrm{Cd}$, and $\mathrm{Ni}$ contents of soils and waters and, therefore, have an effect on the metal contents of vegetables (Alegria et al., 1991). Vegetables absorb heavy metals from the soil as well as from surface deposits on the parts of vegetables exposed to polluted air. Moreover, the presence of heavy metals in fertilizers contributes an additional source of metal pollution for vegetables (Yusuf et al., 2003). Accumulation of heavy metals by plants may depend on plant species and soil properties. These heavy metals are not abundant in soil, but there may be an accumulation of these heavy metals through urban wastes and industrial effluents. The uptake of heavy metals in cereals and vegetables is likely to be higher and accumulation of these toxic metals in human body created growing concern in the recent days. Ground water in Punjab has been contaminated by $\mathrm{Hg}$ and $\mathrm{Pb}$ to such an extent that it is causing DNA of the people, who drink it, to mutate (Bajwa, 2008).

\section{CONCLUSION}

The principal mechanism for overcoming any difficulties relating to reusing effluent for irrigation of crops is the pre-treatment of the recycled effluent. The risk from microbial pathogens is significantly reduced with the treatment of water. Treatment of recycled effluent also reduces the concentration of organic and inorganic nutrients, trace organics and heavy metals. The major contaminant that is difficult to remove from recycled effluent is salt and other cations and anions. The only effective treatment mechanism to remove salt molecules and ions is reverse osmosis membrane filtration. Such a high level of treatment is far too expensive to be economically viable therefore an alternative advanced cost-effective, low-tech 'green' technology called phytoremediation can be adopted to remediate the environmental contaminants such as heavy metals, trace elements, organic compounds, and radioactive compounds from effluent. 


\section{References}

[1] Eguabor V., STAN Journal Environmental Education series (2) (1998) 49.

[2]Schiffenbauer M., Stotzky G, Bulletin of Environmental and Contamination Toxicology 28 (1982) 193-202.

[3].Hari O.M., Singh N., Aryo M.S, J. Environ. Biol 15 (1994) 171-175.

[4].Briccoli B C., Basta P., Tocci C.,Turco D., Olivae 53(1994) 35-38.

[5].Goel P K., Kulkarni S. M., Jour. of Environ. and Pollution 1 (1994) 35-53.

[6].Chien H.F., Kao C.H., Plant Sci 156 (2000): 111-115.

[7]. Owa F. W., International Letters of Natural Sciences 3 (2014) 1-6.

[8]. Feachem D.G., Bradley D.J., Garelick H., Mara, D.D. (1983) Sanitation and disease: health aspects of excreta and wastewater management. John Wiley and Sons, Bath.

[9]. Haas C N., Rose J.B., Gerba C.P., (1999) Quantitative Microbial Risk Assessment. John iley and Sons, New York.

[10]. Toze S., Water Research 33 (1999): 3545-3556

[11]. Gennaccaro AL., McLaughlin M.R., Quintero-Betancourt W., Huffman D.E., Rose J.B., Applied and Environmental Microbiology 69 (2003) 4983-4984.

[12]. Alegria A., Barberfi R., Boluda R., Errecalde F., Farr R., Lagarda M.J., Fresenius J. Anal. Chem. 339 (1991) 654-657.

[13]. Yusuf A.A., Arowolo T.A., Bamgbose O., Food Chem. Toxicol. 41 (2003) 375-378.

[14]. Bajwa H., (2008). Water contamination causing DNA mutation. The Indian Express, pp. 5, Feb. 16, Chandigarh edition, India. 